\title{
Fuzzy modeling of the risk of cacao moniliasis occurrence in Bahia state, Brazil
}

\author{
Samira L. H. de Almeida ${ }^{1}$, Samuel de A. Silva², Julião S. de S. Lima², Jorge T. F. Rosas ${ }^{3} \&$ \\ Vinicius A. Capelini
} ${ }^{1}$ Universidade Estadual Paulista "Júlio de Mesquita Filho"/Faculdade de Ciências Agrárias e Veterinárias/Departamento de Engenharia Rural, Jaboticabal,
SP, Brasil. E-mail: samiraluns@hotmail.com (Corresponding author) - ORCID: 0000-0001-6900-1616
${ }^{2}$ Universidade Federal do Espírito Santo/Departamento de Engenharia Rural, Alegre, ES, Brasil. E-mail: samuel.assilva@gmail.com - ORCICD: 0000-
0002-0718-7328; limajss@yahoo.com.br - ORCID: 0000-0002-8178-3937; vinicius91ac@hotmail.com - ORCID: 0000-0002-8196-771X
${ }^{3}$ Universidade de São Paulo/Escola Superior de Agricultura “Luiz de Queiroz"/Departamento de Solos e Nutrição de Plantas, Piracicaba, SP, Brasil. E-mail:
jorgetadeufimrosas@hotmail.com - ORCID: 0000-0002-3244-4816

\begin{abstract}
This work aimed to determine potential areas for the establishment of cocoa moniliasis in Bahia state, Brazil, by means of fuzzy logic, based on historical datasets of temperature and air relative humidity, available for 519 measurement points distributed throughout the state of Bahia. The data were initially submitted to a descriptive statistical analysis. The spatial variability was determined through geostatistical analysis, followed by interpolation to map the spatial-temporal structure dependence of the phenomenon. Simulations of continuous pixel-to-pixel classification of variables were performed using fuzzy mapping to model the climatic risk of disease establishment. The exponential fuzzy model was applied to temperature data, while the linear model was used for air relative humidity data. The potential areas were defined for each month, using data of temperature and air relative humidity. The fuzzy models used allowed for modeling of the climatic risk of cocoa moniliasis establishment. A large area of the state is at high risk of disease, thus requiring mitigating measures to avoid the pathogen's introduction and dissemination.
\end{abstract}

Key words: Moniliophthora roreri, Theobroma cacao, climate change, geostatistics, precision phytopathology

\section{Modelagem fuzzy do risco de ocorrência da monilíase do cacaueiro no Estado da Bahia}

\begin{abstract}
RESUMO: Com este trabalho objetivou-se definir áreas potenciais de estabelecimento da monilíase do cacaueiro no Estado da Bahia, por meio da lógica fuzzy, com base em séries históricas de temperatura e umidade relativa do ar, disponíveis para 519 pontos de medição distribuídos no Estado da Bahia. Os dados foram submetidos inicialmente a uma análise estatística descritiva. A variabilidade espacial foi determinada através de análise geoestatística, seguida de interpolações para mapear a estrutura da dependência espaço-temporal do fenômeno. Para modelar o risco climático de estabelecimento da doença foram realizadas simulações de classificação contínua, pixel-a-pixel, das representações das variáveis, utilizando o mapeamento fuzzy. Aos dados de temperatura, aplicou-se o modelo fuzzy exponencial, enquanto que aos dados de umidade relativa do ar, o modelo utilizado foi o linear. As definições de áreas potenciais foram realizadas para cada mês, utilizando a informação conjunta das pertinências da temperatura e da umidade relativa do ar. Os modelos fuzzy utilizados permitiram modelar o risco climático de estabelecimento da monilíase no Estado da Bahia. A maior extensão do Estado da Bahia tem riscos elevados para o desenvolvimento da doença, o que exige medidas mitigadoras para evitar a introdução e disseminação do patógeno.
\end{abstract}

Palavras-chave: Moniliophthora roreri, Theobroma cacao, mudança climática, geoestatística, fitopatologia de precisão

Editor responsible: Walter Esfrain Pereira

Ref. 210990 - Received 08 Aug, 2018 • Accepted 03 Feb, 2020 • Published 04 Mar, 2020 


\section{INTRODUCTION}

Cacao is a crop of great economic importance for Brazil, especially for Bahia state, while being susceptible to several pathogens that can affect production significantly. Moniliasis (Moniliophthora roreri) is one of the major diseases affecting cocoa crops, accounting for about $40 \%$ of the annual production losses in countries where its occurrence is recorded (Álvarez et al., 2014). Although it has not been detected until now in Brazil, it is considered a threat since recent surveys have detected the disease at the border between Brazil and Peru (Santana \& Tarazi, 2017).

Given the possibility of this disease entering the national territory, it is essential to study the climatic conditions of the main cocoa-producing regions of Brazil, in order to determine the possible impacts on the crops. In this context, agrometeorological modeling of climatic risk emerges as a tool to model real situations using mathematical functions, creating simplified representations of a complex system (Silva \& Lima, 2012). In this way, mathematical modeling allows estimation of the establishment of diseases as a function of environmental variables (Juroszek \& Tiedemann, 2015).

Agrometeorological modeling functions as an important tool to help decision-making during agricultural production (Pezzopane et al., 2010). Through mathematical, statistical and probabilistic functions, models are built to simulate real scenarios, based on integration and analysis of the behavior of the edaphoclimatic components responsible for crop production.

The risk of introducing moniliasis to Brazil and its importance to the cocoa economy require researches to assist in understanding the various related aspects. Models based on computational intelligence such as fuzzy logic, capable of modeling the uncertainties associated with natural phenomena, define more efficiently the areas at higher climatic risk for the establishment of pests and diseases in agriculture.

Bahia state with its extensive territory presents high microclimatic variations throughout the area; therefore, it is possible to define potential areas for the occurrence of the Moniliophthora roreri fungus and its transition limits, helping to propose mitigating actions to avoid introducing the disease and also understanding the pathological system studied.

The aim of this study was to define potential risk areas for the establishment of moniliasis in Bahia state using fuzzy logic, based on historical datasets of temperature and air relative humidity.

\section{Material ANd Methods}

The study covered an area of $567,295 \mathrm{~km}^{2}$ in Bahia, in Northeastern Brazil, with approximately $70 \%$ of the area between 300 and $900 \mathrm{~m}$ high and 23\% below $300 \mathrm{~m}$.

The predominant climate is tropical, characterized by high temperatures ( $\operatorname{Max}-26.4^{\circ} \mathrm{C}$; Min $-19.7^{\circ} \mathrm{C}$ ) practically all year, except for the Espinhaço mountain range, where temperatures are milder (Tanajura et al., 2010). The Bahia backlands, known as Sertão Bahiano, have a semi-arid climate with little precipitation, not exceeding $500 \mathrm{~mm}$ per year and irregular as well with long periods of drought. However, in some coastal regions, the rainfall may exceed $1,500 \mathrm{~mm}$.

This study used the historical averages of temperature and air relative humidity for 519 measurement points throughout Bahia in the period between 1961 and 2009. The data were obtained from the Climate Research Unit (CRU) of the Agência Nacional de Águas, ANA, and of the Instituto Nacional de Meteorologia, INMET.

The data were submitted to a descriptive and exploratory analysis, determining position (mean, median, minimum and maximum values) and dispersion (standard deviation, variance and coefficient of variation) measurements. The normality hypothesis was tested by the Shapiro-Wilk method at $\mathrm{p} \leq 0.05$, followed by geostatistical analysis to evaluate the intrinsic stationarity hypothesis by adjusting a theoretical model to the experimental variogram, estimated by Eq. 1:

$$
\gamma^{*}(\mathrm{~h})=\frac{1}{2 \mathrm{~N}(\mathrm{~h})} \sum_{\mathrm{i}=1}^{\mathrm{N}(\mathrm{h})}\left[\mathrm{z}\left(\mathrm{x}_{\mathrm{i}}\right)-\mathrm{z}\left(\mathrm{x}_{\mathrm{i}}+\mathrm{h}\right)\right]^{2}
$$

where:

$\gamma^{*}(h)$ - estimated semivariance for each vector $h$;

$\mathrm{N}(\mathrm{h})$ - number of pairs of values $\mathrm{z}\left(\mathrm{x}_{\mathrm{i}}\right)$ for each vector $\mathrm{h}$; and,

$x_{i} \quad$ - spatial position of the variable $z$.

A mathematical function is fitted to the point cloud [h, $y(h)$, with the following parameters: nugget effect $\left(C_{0}\right)$, corresponding to the value at which it intersects with the semivariance axis; sill value $\left(\mathrm{C}_{0}+\mathrm{C}_{1}\right)$, approximately equal to the value of the data variance; and range (a), representing the distance at which the variogram reaches the sill value, and the region of spatial dependency between the samples.

For estimating the theoretical semivariance, the exponential, spherical, Gaussian and linear models with the threshold were tested. The models were chosen to minimize the sum of squared errors, those with the highest coefficient of multiple determination $\left(\mathrm{R}^{2}\right)$ of the adjustments of a variogram theoretical model to the empirical model, the lowest square sum of residuals (SSR) and highest coefficient of determination $\left(\mathrm{R}^{2}\right)$ being selected in the cross-validation.

After the geostatistical analysis, the data were interpolated to map the structure of spatial dependence and to evaluate its temporal stability throughout the state of Bahia. Interpolation was performed using the ordinary kriging geostatistical interpolator.

Continuous pixel-by-pixel classification of the variables was performed using fuzzy mapping to model climatic risk for the establishment of moniliasis in Bahia. The monthly averages of temperature and air relative humidity were submitted to a continuous classification using the exponential and linear association functions, respectively, as shown below:

- Temperature dataset

$$
\begin{gathered}
\mathrm{MF}_{\mathrm{A}}(\mathrm{z})=\frac{1}{1+\mathrm{IF}(\mathrm{z}-\mathrm{LL})^{2}} \quad \text { if } \mathrm{z}<\mathrm{LI} \\
\mathrm{MF}_{\mathrm{A}}(\mathrm{z})=1 \quad \text { if } \mathrm{LI} \leq \mathrm{z} \geq \mathrm{LS}
\end{gathered}
$$




$$
\mathrm{MF}_{\mathrm{A}}(\mathrm{z})=\frac{1}{1+\mathrm{IF}(\mathrm{z}-\mathrm{UL})^{2}} \quad \text { if } \mathrm{z}<\mathrm{LS}
$$

- Relative humidity dataset

$$
\begin{gathered}
\mathrm{MF}_{\mathrm{A}}(\mathrm{z})=0 \quad \text { if } \mathrm{z} \leq \mathrm{LI} \\
\mathrm{MF}_{\mathrm{A}}(\mathrm{z})=\frac{1 / \alpha}{\mathrm{z}-\mathrm{LL}} \quad \text { if } \mathrm{LI}<\mathrm{z}>\mathrm{LS} \\
\mathrm{MF}_{\mathrm{A}}(\mathrm{z})=1 \quad \text { if } \mathrm{z} \geq \mathrm{LS}
\end{gathered}
$$

where:

$\mathrm{MF}_{\mathrm{A}}$ - membership function of the variable $\mathrm{z}$;

IF - inclination factor, considered equal to 0.05 , according to Silva et al. (2010);

UL and LL - values of the class boundaries of two fuzzy sets belonging to a set $\mathrm{A}$; and,

$\alpha=\mathrm{UL}-\mathrm{LL}$.

The fuzzy transition zone is given by the lines' slope for the set A with increasing values (air relative humidity) and exponential values (temperature).

The epidemiological limits of cocoa moniliasis were established as a temperature of 22 to $30{ }^{\circ} \mathrm{C}$ and relative humidity of $80 \%$.

These limits were established as favorable to highly favorable conditions for the establishment of cacao moniliasis, based on the work of some authors (Hernandez, 1991; PhillipsMora et al., 2007).

The combined effect of climate variables was measured using map algebra functions and fuzzy operator of the convex mean, according to Silva et al. (2010). Equal weight was attributed to all variables, in which they contribute equally to the possibility of the establishment of cacao moniliasis in Bahia state.

Areas at risk for the establishment of moniliasis were mapped for each month of the year, identifying regions with more or less pertinence to the ideal development conditions for the fungus.

\section{Results AND Discussion}

The descriptive analysis results of the temperature and air relative humidity are shown in Table 1 . The central tendency measurements (mean and median) for both temperature and relative humidity were close for each month.

The mean and median proximity values indicate a symmetrical distribution, a fact confirmed by the asymmetry (Cs) values close to zero (Santos et al., 2013). Despite this, the variables studied did not have a normal distribution, indicated by the Shapiro-Wilk test results. Normal distribution, unlike other statistical and probabilistic methods, is not a presupposition of the methods of spatial analysis and fuzzy classification used in this work, and it is recommended only

\begin{tabular}{|c|c|c|c|c|c|c|}
\hline Month & Mean & Median & $\begin{array}{l}\text { CV } \\
(\%)\end{array}$ & Cs & Ck & $W$ \\
\hline \multicolumn{7}{|c|}{ Temperature } \\
\hline Jan & 25.42 & 25.40 & 3.98 & -0.07 & -0.12 & $\star$ \\
\hline Feb & 25.72 & 25.70 & 3.63 & -0.11 & -0.26 & $\star$ \\
\hline Mar & 25.51 & 25.60 & 4.30 & -0.33 & -0.14 & * \\
\hline Apr & 24.56 & 24.70 & 4.87 & -0.27 & -0.11 & * \\
\hline May & 22.86 & 23.00 & 6.48 & -0.39 & -0.12 & * \\
\hline Jun & 21.87 & 21.95 & 5.72 & -0.36 & -0.18 & * \\
\hline Jul & 21.29 & 21.40 & 5.80 & -0.40 & -0.04 & * \\
\hline Aug & 21.94 & 21.85 & 5.89 & -0.07 & -0.22 & * \\
\hline Sep & 23.54 & 23.30 & 6.71 & 0.09 & -0.22 & * \\
\hline Oct & 24.94 & 24.70 & 6.86 & -0.05 & -0.23 & * \\
\hline Nov & 24.81 & 24.85 & 6.94 & 0.02 & -0.18 & $\star$ \\
\hline Dec & 24.91 & 25.00 & 4.89 & -0.16 & -0.18 & * \\
\hline \multicolumn{7}{|c|}{ Air relative humidity } \\
\hline Jan & 77.29 & 77.12 & 3.57 & -0.09 & -0.32 & $\star$ \\
\hline Feb & 76.58 & 76.41 & 3.94 & -0.07 & -0.27 & * \\
\hline Mar & 76.86 & 76.65 & 3.76 & 0.00 & -0.42 & * \\
\hline Apr & 78.79 & 78.80 & 2.78 & -0.21 & -0.51 & * \\
\hline May & 80.88 & 81.09 & 1.57 & -0.81 & -0.20 & $\star$ \\
\hline Jun & 81.69 & 81.92 & 0.87 & -1.03 & 0.08 & * \\
\hline Jul & 82.12 & 82.22 & 0.36 & -1.07 & 0.13 & $\star$ \\
\hline Aug & 81.62 & 81.92 & 1.03 & -1.10 & 0.08 & $\star$ \\
\hline Sep & 80.08 & 80.85 & 2.55 & -1.01 & -0.13 & $\star$ \\
\hline Oct & 77.40 & 78.51 & 4.64 & -0.76 & -0.39 & * \\
\hline Nov & 77.82 & 78.00 & 2.60 & -0.57 & -0.28 & * \\
\hline Dec & 78.25 & 78.21 & 3.31 & -0.30 & -0.41 & * \\
\hline
\end{tabular}
when the tails of the distribution are not very elongated (Silva
Table 1. Descriptive analysis of the climatic variables temperature and air relative humidity in Bahia state, Brazil

CV - Coefficient of variation; Cs - Asymmetry coefficient; Ck - Curtosis coefficient; ${ }^{*}$ Non-normal distribution by the Shapiro-Wilk test (W) at $\mathrm{p} \leq 0.05$

\& Lima, 2012). This avoids the so-called proportional effect, which impairs estimates by geostatistical interpolators (Silva et al., 2010).

Environmental conditions strongly influence the development and progress of moniliasis. The cycle begins at low humidity, but germination of the conidiospores, fungal spores, occurs at higher air relative humidity and temperature (Álvarez et al., 2014). Rios-Ruiz (2004) suggested that these are the climatic variables most affecting development of the pathogen causing cocoa moniliasis.

The results in Table 1 allow the identification of two distinct seasons. The first season with higher average temperatures, varying from 24.81 to $25.72{ }^{\circ} \mathrm{C}$, extends for much of the year (from October to April) whereas the average air relative humidity is lower compared to the other months of the year, with a maximum value of $78.79 \%$.

The second season with milder temperatures, up to an average of $22.86{ }^{\circ} \mathrm{C}$, lasts from May to August, while the air relative humidity has a minimum average of $80.88 \%$. The high air relative humidity during the winter in part of the Brazilian Northeast results from the meeting of two air masses, the Atlantic tropical and Atlantic polar air masses. This is responsible for frequent frontal rains on the Northeastern coast, probably increasing the risk of establishment of phytopathogenic fungi in this area at this time of year.

Table 2 shows the results obtained for geostatistical analysis of the temperature and air relative humidity variables.

All months presented spatial dependence with adjustment to the spherical ( 8 months), Gaussian (1 month) and exponential (15 months) models. All models were fitted with coefficients of determination higher than $90 \%$. Similar 
Table 2. Geostatistical analysis of the temperature and air relative humidity

\begin{tabular}{|c|c|c|c|c|c|c|c|}
\hline Month & Model & $\mathbf{C}_{0}$ & $C_{0}+C$ & $\begin{array}{c}\text { a } \\
\text { (m) }\end{array}$ & $\begin{array}{l}\text { SDI } \\
(\%)\end{array}$ & $\mathbf{R}^{2}$ & $\begin{array}{l}\mathrm{R}^{2} \\
\text { (VC) }\end{array}$ \\
\hline \multicolumn{8}{|c|}{ Temperature } \\
\hline Jan & EXP & 0.06 & 0.40 & 360000 & 85.5 & 0.99 & 0.73 \\
\hline Feb & EXP & 0.06 & 0.35 & 329000 & 84.1 & 0.99 & 0.72 \\
\hline Mar & EXP & 0.06 & 0.46 & 251000 & 87.7 & 0.99 & 0.72 \\
\hline Apr & EXP & 0.08 & 0.59 & 316000 & 86.9 & 0.99 & 0.73 \\
\hline May & EXP & 0.12 & 1.16 & 693000 & 89.8 & 0.99 & 0.79 \\
\hline Jun & EXP & 0.09 & 0.78 & 573000 & 88.5 & 1.00 & 0.78 \\
\hline Jul & EXP & 0.10 & 0.73 & 489000 & 86.1 & 0.99 & 0.75 \\
\hline Aug & EXP & 0.12 & 0.91 & 786000 & 86.8 & 0.99 & 0.75 \\
\hline Sep & SPH & 0.18 & 1.50 & 773000 & 88.3 & 0.99 & 0.80 \\
\hline Oct & SPH & 0.32 & 1.62 & 715000 & 80.3 & 0.99 & 0.76 \\
\hline Nov & SPH & 0.22 & 1.78 & 754000 & 87.6 & 0.96 & 0.79 \\
\hline Dec & EXP & 0.07 & 0.58 & 364000 & 88.4 & 0.99 & 0.77 \\
\hline \multicolumn{8}{|c|}{ Air relative humidity } \\
\hline Jan & EXP & 0.01 & 1.43 & 192000 & 99.8 & 1.00 & 0.80 \\
\hline Feb & EXP & 0.02 & 1.78 & 210000 & 99.1 & 1.00 & 0.82 \\
\hline Mar & EXP & 0.02 & 1.71 & 177000 & 98.6 & 1.00 & 0.79 \\
\hline Apr & EXP & 0.00 & 0.93 & 205000 & 99.7 & 1.00 & 0.80 \\
\hline May & SPH & 0.04 & 0.19 & 100000 & 81.7 & 0.96 & 0.78 \\
\hline Jun & EXP & 0.01 & 0.10 & 160000 & 99.7 & 0.99 & 0.69 \\
\hline Jul & EXP & 0.01 & 0.02 & 112000 & 99.9 & 0.99 & 0.57 \\
\hline Aug & SPH & 0.03 & 0.10 & 126000 & 78.2 & 0.95 & 0.70 \\
\hline Sep & GAU & 0.25 & 1.81 & 743000 & 86.2 & 0.99 & 0.82 \\
\hline Oct & SPH & 0.35 & 5.22 & 790000 & 93.2 & 0.98 & 0.84 \\
\hline Nov & SPH & 0.30 & 1.39 & 740000 & 78.3 & 0.98 & 0.65 \\
\hline Dec & SPH & 0.29 & 1.83 & 468000 & 84.3 & 0.97 & 0.77 \\
\hline
\end{tabular}

GAU - Gaussian; SPH - Spherical; EXP - Exponential; $C_{0}$ - Nugget; $C_{0}+C$ - Sill; a Range; SDI - Spatial dependence index; $\mathrm{R}^{2}$ - Coefficient of determination of the model; CV - Cross-validation

behavior was observed for the cross-validation, in which the coefficients of determination were higher than 0.5 . Crossvalidation is an important factor to consider when selecting the best fit of a variogram model. Higher values of the crossvalidation coefficient of determination indicate a better fit of the model; the ideal is a value of 1 (Pelissari et al., 2014; Rocha et al., 2015).

The exponential model was the best fit for the temperature of most months, with space dependence range varying from 316 to $786 \mathrm{~km}$. The air relative humidity was also predominantly represented by the exponential model, with range varying from 112 to $210 \mathrm{~km}$. These results indicate that, in general terms, the temperature has less spatial and temporal variability compared to the relative humidity of the air in Bahia. The air relative humidity is expected to vary more than other climatic variables, a behavior resulting from the several components controlling this phenomenon (Jardim, 2011).

In general, temperature was characterized by higher values of the range and presented the greatest spatial continuities from May to November. It is possible to affirm that in the low rainfall period, the difference in temperature is smaller between the municipalities, and more affected by location than any other phenomenon.

The nugget $\left(\mathrm{C}_{0}\right)$ effect values found for both variables are very close to zero, except for the air relative humidity between August and October. Low $\mathrm{C}_{0}$ values, that is, a small random variation, make the estimates of unmeasured locations more precise, through ordinary kriging (Silva et al., 2010).

Both the temperature and air relative humidity showed high spatial dependence, with SDI (spatial dependence index) values above $75 \%$. These values are mainly due to the low discontinuity in the origin of the variograms, evidenced by the low nugget effect values. The SDI values indicate that distribution of air relative humidity is strongly influenced by the distance separating the sampling points for most months. This suggests that only a small part of this variation can be attributed to chance, so estimates based only on mean values would lead to significant errors, especially in studies similar to the one described here.

The spatial continuity was also lower in the period of less rainfall. Cera \& Ferraz (2015) reported that the rainfall regime and other parameters such as cloudiness and amount of radiation incident on the surface affect temperature and air relative humidity significantly. The direct effect of precipitation on air relative humidity can be observed in the semivariance ranges of the variograms over time. As expected, due to the water regime, the greatest spatial continuity was found for the rainy season, except for January and February.

The fuzzy classification allowed the acquisition of monthly maps indicating the risk areas for the establishment of moniliasis in Bahia state (Figures 1 and 2) expressed as pertinence values of temperature and air relative humidity, using the mean convex operator.

Most of the state presents pertinence values close to 1 , that is, with total adhesion to the ideal climate set for pathogen
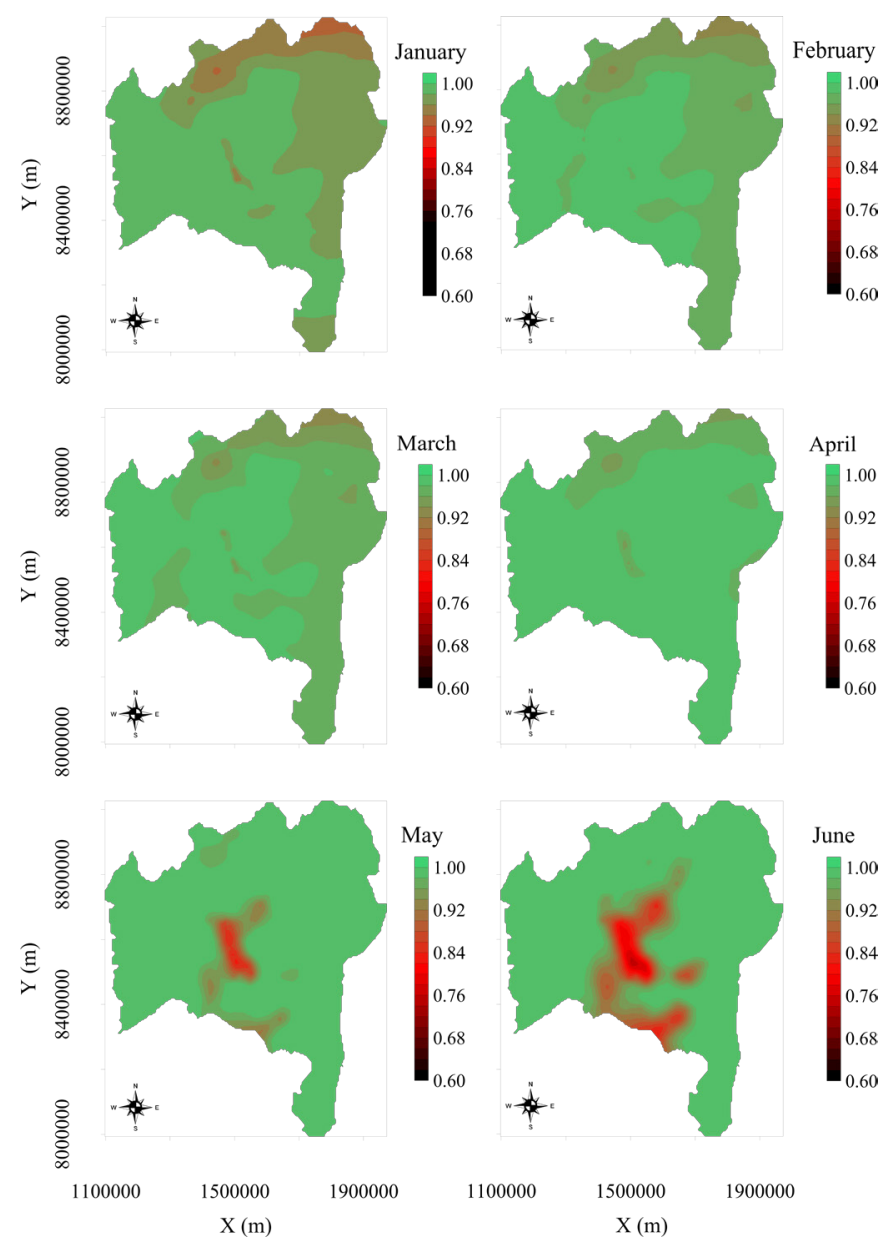

Figure 1. Thematic risk maps for the establishment of cacao moniliasis based on the fuzzy classification of temperature and air relative humidity from January to June 


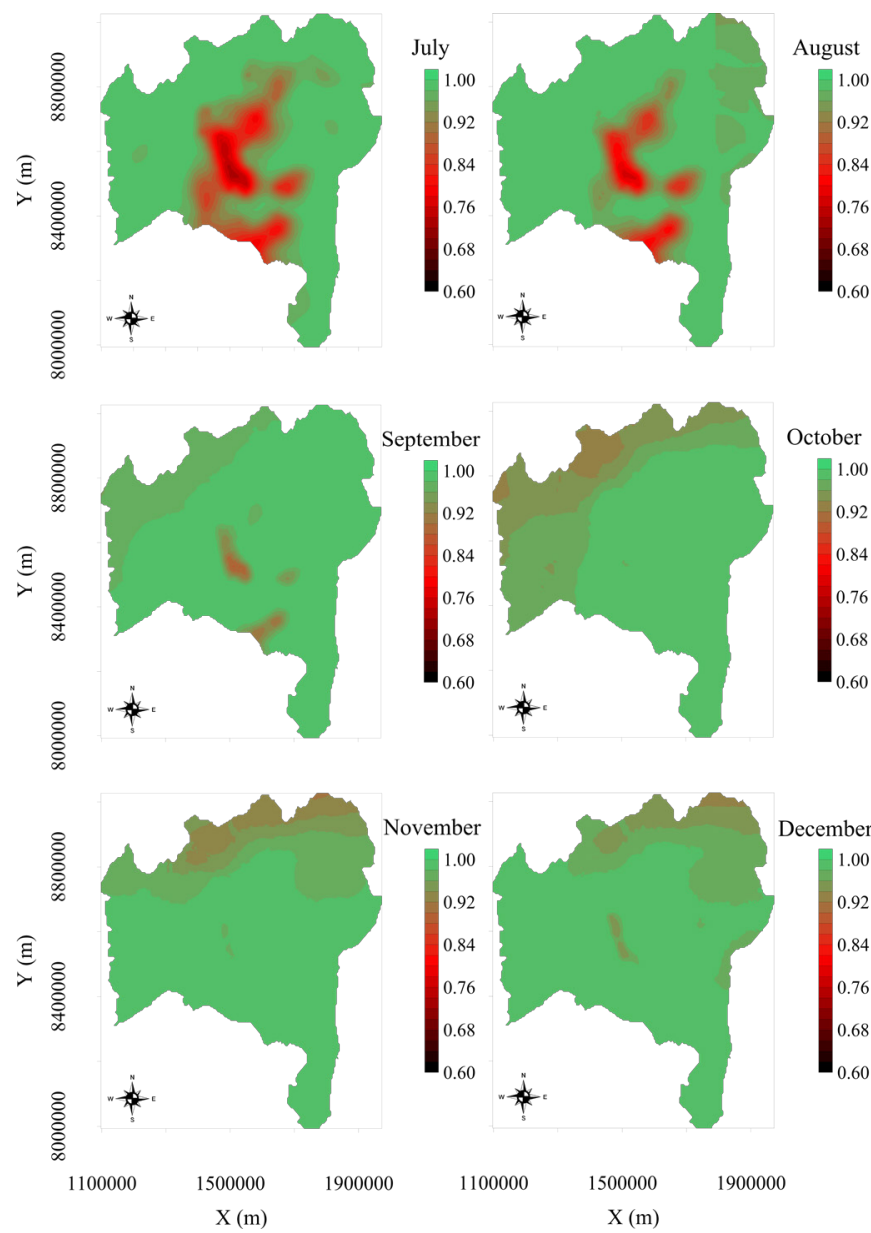

Figure 2. Thematic risk maps for the establishment of cacao moniliasis based on the fuzzy classification of temperature and air relative humidity from July to December

development. No month of the year had relevance less than 0.6 , indicating that the chances of developing moniliasis are higher than $60 \%$ in Bahia state. The months with the greatest variations were May, June, July and August, with pertinence values below 0.84 in most of the central region of the state.

The resulting maps show that Bahia state is a favorable region for the development of cacao moniliasis. From December to March (summer), it can be seen that a large part of the state presents favorable conditions for development of the disease. This result repeated itself from September to December (spring). These seasons have higher temperatures compared to the rest of the year, which coupled with higher rainfall creates a more appropriate growth environment for the Moniliophthora roreri pathogen.

In the other seasons of the year (autumn and winter), between March and September, most of the state also presented pertinence values close to 1 . However, some regions, especially Chapada Diamantina, had less chance of developing the disease. These higher-altitude areas usually have lower temperatures, especially in winter when they tend to reduce even further. Thus, these regions do not reach the ideal temperature range for moniliasis development; however, they are not traditional areas for cacao cultivation.

Moraes et al. (2012) reported that, in Brazil, the development of moniliasis was more favorable from November to May between 1961 and 1990. This interval is compatible with the time of fruit development, which can lead to large production losses.

In Brazil, the areas with the greatest climatic potential for the occurrence of Moniliophthora roreri are found in the Northeast region, especially in southern Bahia (Moraes et al., 2012). This study focused on the main cocoa-producing region in Southern Bahia, which presents high temperature and air relative humidity during most of the year, making it a high-risk region if the disease were introduced to Brazil.

Moniliasis affects the fruits directly and can cause drastic production losses (Álvarez et al., 2014). In Bahia state, the possible impacts from this disease could be even more significant than in the other cocoa-producing countries of Latin America since this cocoa-producing region in the south of the state has two harvests, the early and the main harvests, while the other producing countries have only one harvest. The early harvest, which occurs during the summer, takes place when there are climatic conditions more favorable to development of the pathogen (Ram et al., 2004).

Noting the damage that this disease can cause to the state of Bahia, both in the economic and social spheres, measures must be taken to avoid the introduction of the pathogen to Brazil, since in neighboring countries, such as Colombia, moniliasis has already caused great production losses (Álvarez et al., 2014).

\section{Conclusions}

1. The fuzzy models used are efficient for defining the climatic risk areas for the establishment of moniliasis in Bahia state, Brazil.

2. The fuzzy model allows the most favorable seasons and locations for Moniliophthora roreri fungus development to be established.

3. A large area of Bahia State is highly favorable to the development of cacao moniliasis throughout the year.

\section{Literature Cited}

Álvarez, J. C.; Martínez, S. C.; Coy, J. Estado de la moniliasis del cacao causada por Moniliophthora roreri en Colombia. Acta Agronómica, v.63, p.388-399, 2014. https://doi.org/10.15446/ acag.v63n4.42747

Cera, J. C.; Ferraz, S. E. T. Variações climáticas na precipitação no sul do Brasil no clima presente e futuro. Revista Brasileira de Meteorologia, v.30, p.81-88, 2015. https://doi.org/10.1590/0102778620130588

Hernandez, T. A. Cacao. Sistemas de producción en la Amazonia peruana. Proyecto de promoción agroindustrial AD/PER/86/459 UNFDAC - PNUD/OSP. Tingo Maria, Peru, 1991.

Jardim, C. H. Relações entre temperatura, umidade relativa do ar e pressão atmosférica em área urbana: Comparação horária entre dois bairros no município de São Paulo-SP. Geografias, v.7, p.128-142, 2011.

Juroszek, P.; Tiedemann, A. von. Linking plant disease models to climate change scenarios to project future risks of crop diseases: A review. Journal of Plant Diseases and Protection, v.122, p.3-15, 2015. https://doi.org/10.1007/BF03356525 
Moraes, W. B.; Jesus Júnior, W. C.; Peixoto, L. A.; Moraes, W. B.; Silva, L. G.; Cecílio, R. A.; Alves, F. R. An analysis of the risk of cocoa moniliasis occurrence in Brazil as the result of climate change. Summa Phytopathologica, v.38, p.30-35, 2012. https:// doi.org/10.1590/S0100-54052012000100005

Pelissari, A. L.; Figueiredo Filho, A.; Caldeira, S. F.; Machado, S. A. Geoestatística aplicada ao manejo de povoamentos Florestais de teca, em períodos pré-desbaste seletivo, no Estado do Mato Grosso. Revista Brasileira de Biometria, v.32, p.430-444, 2014.

Pezzopane, J. R. M.; Castro, F. S.; Pezzopane, J. E. M.; Bonomo, R.; Saraiva, G. S. Zoneamento de risco climático para a cultura do café Conilon no Estado do Espírito Santo. Revista Ciência Agronômica, v.41, p.341-348, 2010. https://doi.org/10.1590/ S1806-66902010000300004

Phillips-Mora, W.; Aime, M. C.; Wilkinson, M. J. Biodiversity and biogeography of the cacao (Theobroma cacao) pathogen Moniliophthora roreri in tropical America. Plant Pathology, v.56, p.911-922, 2007. https://doi.org/10.1111/j.13653059.2007.01646.x

Ram, A.; Valle, R. R.; Gardini, E. A. Monília do cacaueiro. São Paulo: Fundação Cargill, 2004. 36p.

Rios-Ruiz, R. A. Epidemiologia e manejo da monilíase do cacaueiro no Peru. Viçosa: UFV, 2004. 91p. Tese Doutorado
Rocha, F. C.; Oliveira Neto, A. M.; Bottega, E. L.; Guerra, N.; Rocha, R. P.; Vilar, C. C. Weed mapping using techniques of precision agriculture. Planta Daninha, v.33, p.157-164, 2015. https://doi. org/10.1590/S0100-83582015000100018

Santana, N. S.; Tarazi, M. F. A. Análise da diversidade de bactérias componentes da porção microbiota do hologenoma do cacaueiro. C\&D-Revista Eletrônica da FAINOR, v.10, p.122-127, 2017. https://doi.org/10.11602/1984-4271.2017.10.1.7

Santos, E. O. de J.; Gontijo, I.; Silva, M. B. da. Planejamento amostral de propriedades químicas do solo em lavoura de café conilon. Coffee Science, v.8, p.423-431, 2013.

Silva, S. de A.; Lima, J. S. de S. Multivariate analysis and geostatistics of the fertility of a humic rhodic hapludox under coffee cultivation. Revista Brasileira de Ciência do Solo, v.36, p.467-474, 2012. https://doi.org/10.1590/S0100-06832012000200016

Silva, S. de A.; Lima, J. S. de S.; Souza, G. S. de; Oliveira, R. B. de; Xavier, A. C. Lógica fuzzy na avaliação da fertilidade do solo e produtividade do café conilon. Revista Ciência Agronômica, v.41, p.9-17, 2010.

Tanajura, C. A. S.; Genz, F.; Araújo, H. A. Mudanças climáticas e recursos hídricos na Bahia: Validação da simulação do clima presente do HadRM3P e comparação com os cenários A2 e B2 para 2070-2100. Revista Brasileira de Meteorologia, v.25, p.345358, 2010. https://doi.org/10.1590/S0102-77862010000300006 